\title{
The Education of Hungarian Literature in South Korea: Results and Tasks
}

\author{
Jinil Yoo \\ Hungarian Department, Hankuk University of Foreign Studies, Seoul, Republic of Korea \\ Email address: \\ yoojinil@hufs.ac.kr
}

\section{To cite this article:}

Jinil Yoo. The Education of Hungarian Literature in South Korea: Results and Tasks. Science Journal of Education. Vol. 4, No. 2, 2016, pp. 90-94. doi: 10.11648/j.sjedu.20160402.21

Received: April 2, 2016; Accepted: May 8, 2016; Published: May 11, 2016

\begin{abstract}
This study aims to arrange the processes and results of Hungarian literature studies in South Korea and to seek urgent problems and solutions. Up to the present, approximately 1000 students studied Hungarian language and literature at the Department of Hungarian Language established in the Hankuk University of Foreign Studies. The graduates have jobs in a variety of areas, but some of them produce the good results of Hungarian literature education in South Korea. The results are roughly summarized into the two: One is the translation and publication of Hungarian literary works and the other is the study of Hungarian literature from the perspective of Koreans. The outcomes have greatly contributed to the human and cultural exchanges between South Korea and Hungary since the establishment of diplomatic relations between the both countries. They have played an important role, before anything else, in understanding Hungary and Hungarian people. It is true many Hungarian literary works have been translated and studied for 25 years since the Department of Hungarian Language was established, but the current status is considerably pessimistic in many respects. Even the question arises as to whether Hungarian studies will keep alive in the future as well. In conclusion, the urgent solution is to cultivate the next generation of the discipline by employing graduates as full-time professors.
\end{abstract}

Keywords: Hungarian Literature, South Korea, Hungarian Department

\section{Introduction}

The Republic of Korea established diplomatic relations with Hungary, the first of East European countries, in 1989. However, this does not mean there was no diplomatic relation between the both nations before the year of 1989. In 1892, the Kingdom of Joseon (the former name of the Empire of Korea) concluded the Treaty of Friendship, Commerce and Navigation with the Empire of Austria-Hungary. There was an international treaty between the both peoples already in the late 19th century. Regrettably, few practical exchanges were made amidst turbulent international conditions, including World War I and World War II. Any exchange was completely blocked, especially by the different political systems of the two countries after the end of World War II.

"In February 1989, South Korea set up regular diplomatic relations with Hungary as the first of East European countries, with their embassies opened in Seoul and Budapest. As a result, exchanges were expanded in various sectors, including politics, economy, culture and society. Like this, 1989 can be referred to as the first year in which the foundation of Hungarian studies was laid on a full scale in the Republic of Korea. It is true that Hungarian studies were also performed by some scholars before the year, but most of them fell back on English-language materials, not Hungarian-language ones, and were performed as part of East European studies, not on an independent basis. Therefore, it can be said that the bona fide Hungarian studies in South Korea kicked into high gear, as human and academic exchanges were made free after the establishment of diplomatic relations and independent Hungarian studies were implemented on the basis of Hungarian-language materials. From this point of view, the Hungarian studies in the Republic of Korea were led by the HUFS Hungarian Language Department on a full scale, though they were intermittently treated by some scholars at other ROK universities as well. The Hankuk University of Foreign Studies is the only university having a Hungarian 
language department in South Korea."1

Hungarian literature is also educated only at the Department of Hungarian Language, Hankuk University of Foreign Studies, the sole education institution of Hungarian Studies in South Korea. A quarter of a century has passed since Hungarian studies, including Hungarian literature, began to be pursued in 1989. In the meantime, diverse Hungarian literary works have been translated into Korean and studied in South Korea. This is why it is very significant for the scholars of Hungarian literature to reflect on the outcomes of Hungarian studies in South Korea at this point in time. Until now, the study of Hungarian literature has been restricted to individual writers and works with no view of the whole reception of Hungarian literature in the Republic of Korea. The only exception is Jinil Yoo, who mentions the introduction of Hungarian literature simply, while addressing Hungarian studies in South Korea. ${ }^{2}$ Therefore, the present study, which is the first full-scale attempt of its kind, aims to arrange the processes and results of Hungarian literature studies in South Korea and to seek urgent problems and solutions.

\section{Beginning of Hungarian Literature Education in South Korea}

There should be 3-8 keywords in the paper. The keywords should be separated by commas. The study of a foreign language is prerequisite to that of literary works written in the language. Indeed, it is not completely impossible to understand a foreign literature using translated literary works, but it is possible to gain a deeper understanding of the literature, only when the corresponding language is learned. The learning of a foreign language is essential for the study of its literature. Therefore, both Hungarian language and literature are taught at the Department of Hungarian Language, Hankook University of Foreign Studies. ${ }^{3}$ The current curriculum of the same department is as follows:

"The curriculum puts emphasis on a high level of Hungarian language ability, followed by the correct understanding of Hungarian and mid-European politics, economy, society, culture, history and tradition. Basically, freshman and sophomore programs are led by the lectures for fostering Hungarian language abilities. In the freshman year, students take classes on basic-level Hungarian grammar, translation, conversation, audio-visual learning ten hours a week, In the sophomore year, students take classes on Hungarian grammar, translation, conversation six hours a week in the first semester, and eight hours a week in the

[1] Jinil Yoo, Current State and Perspectives of Hungarian Studies in Republic of Korea, Conference Celebrating the 25th Anniversary of the Establishment of Diplomatic Relations between Korea and Hungary. 2014.

2 Jinil Yoo, Current State and Perspectives of Hungarian Studies in Republic of Korea, in: Conference Celebrating the 25th Anniversary of the Establishment of Diplomatic Relations between Korea and Hungary.

[3] Jinil Yoo, “An Interlanguage Model of Korean Students Learning Hungarian”, The Second International Forum on Communication Studies of Language and Rhetoric, pp.131-138, 2013. second semester, with two hours added to advanced Hungarian grammar. To stimulate students' interest in Hungarian studies, the introduction to Hungarian studies is offered for one year in the freshman year. In the sophomore year, the classes, such as Hungarian cultural history are opened to provide students with indispensable Hungaryrelated knowledge. The junior and senior programs offer deep and refined knowledge with classes such as politics, economy, society, culture, linguistics and literature. Especially, the junior program opens an one-year class on Hungarian proficiency test to objectively measure the ability of the Hungarian language, which entitles students to take the FLEX test organized by the Hankuk University of Foreign Studies. To cope with changes efficiently, the curriculum is always open to partial or total renovation and professors are to be easily changed to secure new and diverse perspectives. In addition, the classes on Mid-East European politics, economy, culture and literature, which are open to the departments of East European languages (Hungarian, Czech, Slovak, Polish, Romanian, Serbian and Croatian), have been opened to enable to study Hungary in a mid-East European perspective." ${ }^{\circ}$ As seen in the above, the curriculum focuses on the learning of Hungarian language for freshman and sophomore students, whereas consisting of diverse fields of Hungarian studies for junior and senior students. Especially, literary courses are offered mainly in the junior and senior years. Wanting to choose literature as a major, students can enter the graduate school.

\section{The Results of Hungarian Literature Education in South Korea}

Up to the present, approximately 1000 students studied Hungarian language and literature at the Department of Hungarian Language established in the Hankook University of Foreign Studies. The graduates have jobs in a variety of areas, but some of them produce the good results of Hungarian literature education in South Korea. The results are roughly summarized into the two: One is the translation and publication of Hungarian literary works and the other is the study of Hungarian literature from the perspective of Koreans. The outcomes have greatly contributed to the human and cultural exchanges between South Korea and Hungary since the establishment of diplomatic relations between the both countries. They have played an important role, before anything else, in understanding Hungary and Hungarian people.

\subsection{The Translation of Hungarian Literary Works}

The translators of Hungarian literature could be categorized into three groups. The first group refers to the writers who did not major in Hungarian literature, but

[4] Jinil Yoo, Current State and Perspectives of Hungarian Studies in Republic of Korea, Conference Celebrating the 25th Anniversary of the Establishment of Diplomatic Relations between Korea and Hungary, 2014. 
retranslated Hungarian literary works from third languages. The second group consists of those who majored in Hungarian literature, but retranslated Hungarian literary works from third languages for want of proficiency in Hungarian. The third group is the people who majored in Hungarian literature in South Korea, obtained $\mathrm{PhD}$ in Hungarian literature in Hungary, and translated Hungarian literary works from Hungarian.

The first group retranslated Hungarian literary works mostly from English, Japanese and French from the late 1980s through the early 1990s. None of East European literary works was introduced into South Korea before the establishment of diplomatic relations between South Korea and the Communist bloc. After national division in 1945, the Korean people in the southern or northern part held their own system alone sacred, while ignoring and showing enmity toward the other party completely. Under such a condition, the reception of foreign literature was obliged to be limited to the specific countries that corresponded to South Korea in system. After 1945 in South Korea, foreign literature always meant Western literature, especially American, British, French, and German literature, and it was a taboo issue to mention the literature of Soviet Union or East Europe. But with the advent of the 1970s, the thoroughly pro-Western view was broadened towards the third world, and in the late 1980s, the taboos from the Cold War days began to disappear little by little, making it possible for Russian and East European literature to be introduced into South Korea, though peripheral and fragmentary. ${ }^{5}$ Against this background, Kim Sukhee retranslated the works of Déry Tibor, who represented the Hungarian literature from the liberation of 1945 till before the Anti-Soviet revolution of 1956, Sánta Ferenc and Fejes Endre, who represent the generation after 1956, and Konrád György, who represents a new literary trend after the late 1960s, into Korean for the first time. Among Déry Tibor's works, Niki-egy kutya története (The Story of a Dog) was introduced that unveils human truth in the extreme circumstances of love between human and dog and of politics in a police state. Among Fejes Endre's works, Rozsdatemetö (The Yard of Scrap-Iron) was introduced that shows a petty bourgeois life prevailing in the then labor class through the history of a worker's family. Among Sánta Ferenc's works, Husz óra (Twenty Hours) was introduced in which a young journalist gives a 20 -hour report of a village, following up the clues to the incidents that occurred in the village over the last ten years and the tragedy that still dominates the life and inner wold the villagers. Among Konrád György's works, A látogató (Visitor) was introduced that takes a diary form of $\mathrm{T}$ who works at the division for child welfare, sometimes standing by the Establishment by blaming would-be suicides, criminals, alcohol addicts, and mental disorder patients for weakness and laziness, and sometimes standing by them by criticizing the rigidity of bureaucracy.

[5] Kim Haksoo et al., The Collected Works of Contemporary Soviet Union and East European Literature, 1990, Seoul: Jungangilbo
Most of the second group engaged in translation in the 2000s. They studied Hungarian literature mostly in Germany, which led them to adopt German texts as translation originals. Jung Bangkyu could be referred to as a representative translator of the second group. He studied German literature at Seogang University in Seoul, and then changed his major into Hungarian literature at the University of Hamburg in Germany. His translation is mostly a retranslation from German. He has translated a total of five works: Szabó Magda's Az öz, Freskó, Örkény István's Tóték, Kosztolányi Dezsö's Édes Anna and Pacsirta $^{6}$, and Gárdonyi Géza's $A$ lámpás. Kim Insoon could be called a translator of the same group as well. She also majored in German literature at Korea University in Seoul, but studied Hungarian literature at the University of Karlsruhe in Germany. She translated only the works of one Hungarian writer: A Gyertyák Csonkig Égnek, Eszter hagytéka, Die Jungen Rebellen, Ég és föld, Csutora, AZ IGAZI/JUDIT. In addition, Im Wangsoon retranslated Márai Sándor's Szerelem from French. Kang Haekyung retranslated Válás Budán from German. In the former period, translated works were mostly those which make it possible to presume a slice of the Hungarian society in the socialist system. On the contrary, the translated works in the 2000s are characterized by showing the individual features of writers rather than the social aspects of the socialist system. The works in this period are higher in quality than those in the former period. For example, Szabó Magda, a representative female writer, chiefly wrote the works describing subtle female mentality. Örkény István's works mainly satirized social conditions by grotesque and irony. Kosztolányi Dezső, the so-called most intellectual writer in Hungary, published the works of various trends, such as impressionism, Freud psychoanalysis, and symbolism. Márai Sándor is a writer of many bestsellers in the whole Europe. ${ }^{7}$ In 2002, Kertész Imre was awarded Nobel Prize in Literature contrary to public expectation, which led to the retranslation of his works from non-Hungarian languages in no more than a few months. Sorstalanság (Fateless), the Nobel Prize-winning work on his life in the Auschwitz Concentration Camp, was retranslated from German. However, Kudarc, a two-part work on his life after the camp, was translated directly from Hungarian. Thereafter, Kaddis meg nem született gyermekért, a three-part work, and Felszámolás, a four-part work, were retranslated from German.

The third group could be referred to as the true fruit of Hungarian literature education in South Korea. They majored in Hungarian literature in South Korea and Hungary, and translated Hungarian works directly from Hungarian. They mostly translated the works of the writers or ages they majored in. Most of the works were published after the 2000s. Han Kyungmin could be called a representative translator of the third group. He translated Kudarc, a work of Kertész Imre, a Nobel Prize in Literature $2014^{8}$, and then Nógrádi Gábor's PetePite, Bálint Ágnes's A szitakötök szigetén, Molnár

[6] Kosztolányi Dezsö, Pacsirta, Seoul: Jimanji, 2015.

[7] Márai Sándor, Die Glut, Seoul: Sol, 2008.

[8] Kertész Imre, Sorstananság, trans: Jinil Yoo, Seoul: Minumsa, 2016. 
Ferenc's A Pál utcai fiúk, and a short story collection of the members of a contemporary literary magazine Nyugat in Hungary. ${ }^{9}$ Yoo Jinil translated Világvége, a short story of a young writer Drágomán György, Barbárok, a short story of a representative realist writer, and then Móricz Zsigmond's válogatott novellái, a short story collection of Móricz Zsigmond. ${ }^{10}$ Besides, he translated Szerelem, a short story of Körösi Zoltán, and Bányavirág, a representative drama of Székely Csaba. With the advent of the 2010s, Kim Bogook translated Rózsakiállítás of Örkény István, a representative Hungarian grotesque writer, and Kim Bogook and Jin Kyungae translated Szerelem and Minotauros of Nádas Péter, a representative Hungarian postmodernist writer.

\subsection{The Study of Hungarian Literature}

The formulas should be clear and editable. They should be numbered as following: At present, there are a total of five scholars of Hungarian literature in South Korea: one full-time professor and four part-time lecturers. All of them belong to Hankook University of Foreign Studies. In South Korea, the education of Hungary language and literature began in 1988, but the study of Hungarian literature began on a full scale in 2002, the year when the graduates of the Department of Hungarian Literature returned home after receiving $\mathrm{PhD}$ from Hungary. Han Kyungmin, a full-time professor, has produced the largest number of studies, which focus on Hungarian oral literature and poetry. His 2004 version of The History of Hungarian Literature is the first of its kind in South Korea. ${ }^{11}$ Additionally, the professors of the departments on East European countries co-published the collections of studies and translations of East European oral literature: A Comparison of Oral Literature between South Korea and East Europe, How Did East Europeans Tell about Their Life, and How Did East Europeans Sing Their Life, which are considered important materials for the study of East European oral tales. Research papers chiefly address Hungarian oral tales and poetry. Among them, the following would be representative: A Study of the Hungarian Transmitted Literature, Hungarian Myth and Its Acculturation in the Contemporary Hungarian Literature, The Genres and Characteristics of Hungarian Folktales, A Study of Petöfi Sándor's Folksongs, The Literature of the Baroque Period in Hungary, and The Hungarian War of Independence and Petöfi Sándor. Yoo Jinil also published a great number of papers on contemporary Hungarian literature, especially the works of Nyugat memebers. Besides, he published over thirty papers on Hungarian oral tales. Of them, the following would be representative: "Attempts at Detraditionalized Poetry by Dezso Tandori - With Special Reference to Neo-Avantgarde and Postmodern Works-", "Structural Characteristics of Imre Kertesz`s Novel: CircularRepetitive and Discontinuous Structures", "Asian Motifs in

[9] Molnár Ferenc, Pál utcai fiuk, Seoul: Biryongso, 2006

[10] Móricz, Zsigmond, Móricz Zsigmond válogatott novellái, Seoul: Jimanji, 2009.

[11] Han Kyungmin, A magyarirodalom története, Seoul: HUFS, 2004.
Hungarian Myths, with Special Reference to the Identity of the Hungarian People", "An Analysis of the Main Motifs in Moricz's Realistic Short Stories, "A Psychoanalytic Approach to Traumas in Az öz", "The Motifs of Submergence in the Creation Myths around the World: A Comparison With Regard to the Finno-Ugric Tribes and Their Neighboring Ones", "Grotesque and Irony as Dual Techniques in Tóték of István Örkény".

Besides, a total of eight students graduated from the Department of Hungarian Language and received MA at the graduate school of the same university. There is a doctorate program at the graduate school, but no student has yet been enrolled in the program. Their master theses are as follows:

Table 1. List of Master Theses.

\begin{tabular}{|c|c|}
\hline Mame & Title \\
\hline Koh Hyungjung & $\begin{array}{l}\text { A Comparison of Folk Song Poetry between Petofi } \\
\text { Sándor and Kim Sowol }\end{array}$ \\
\hline Kim Boguk & $\begin{array}{l}\text { Örkény István's Drama Tóték from the Perspective of } \\
\text { Absurd Drama }\end{array}$ \\
\hline Jin Kyungae & Irony in Déry Tibor's Niki \\
\hline Choi Eunjung & Death in Móricz Zsigmond's Works \\
\hline Yoon Jihyun & $\begin{array}{l}\text { Master-Maid Relationship in Kosztolányi Dezső's } \\
\text { Édes Anna }\end{array}$ \\
\hline Lee Bora & $\begin{array}{l}\text { Radno'ti Miklo's' Sequence Poem Ecloga: Tension in } \\
\text { Theme and Descriptive Style }\end{array}$ \\
\hline Oh Sunmi & $\begin{array}{l}\text { Az álom - Rakovszky Zsuzsa novellájának értelmezése } \\
\text { narratológiai szempontok alapján }\end{array}$ \\
\hline Lee Gayoung & Symbols in Ady Endre's Poem Léda \\
\hline
\end{tabular}

\section{Conclusion}

This part makes a brief summary of the whole paper. Usually, there should be one paragraph in this part. Currently, the education of Hungarian language and literature faces crisis in many ways in South Korea. When the Department of Hungarian Language was established in 1988, there was a general state of expectancy towards East European countries, above all, Hungary in South Korea. Recently, the disappointment at Hungarian economy has continuously caused applicants for the Department to decrease in number and excellent students to evade the application for the Department. It is true this crisis is fundamentally attributed to the political and economic stability in Hungary, but has something to do with domestic factors as well. The most serious problem is that the next generation of the discipline has not yet cultivated. The Department of Hungarian Language has not yet employed any graduate as a full-time professor, unlike the departments of other East European countries, i.e. Poland, Czech Republic, Romania, Croatia. and Serbia that have already employed many graduates as full-time professors. All graduates work as part-time lecturers at the Department of Hungarian Language. Few graduates go on to the graduate school, and the current curriculum is the same as that of 25years ago. The economic crash in South Korea could be referred to as another factor. This makes almost all liberal arts graduates have difficulty finding employment. Most of them get jobs that have nothing to do with their majors. The situation is more serious for 
Hungarian literature. The translation of Hungarian literature is joined by none of about 800 graduates from the Department of Hungarian Language. There are really many Hungarian literary works of high quality, but they are evaded by domestic readers due to the atmosphere of non-reading and the preference for lightweight works. Most of translated Hungarian works are unappealing to domestic readers. In order to revitalize the education of Hungarian literature, it is urgent to foster and support the next generation of the discipline, and to give translators proper treatment under the recognition that translation is the second creation.

It is true many Hungarian literary works have been translated and studied for 25 years since the Department of Hungarian Language was established, but the current status is considerably pessimistic in many respects. Even the question arises as to whether Hungarian studies will keep alive in the future as well. In conclusion, the urgent solution is to cultivate the next generation of the discipline by employing graduates as full-time professors.

\section{References}

[1] Jinil Yoo, "Current State and Perspectives of Hungarian Studies in Republic of Korea," Conference Celebrating the 25th Anniversary of the Establishment of Diplomatic Relations between Korea and Hungary, Korea, pp. 87-95, 2014.
[2] Jinil Yoo, "An Interlanguage Model of Korean Students Learning Hungarian", The Second International Forum on Communication Studies of Language and Rhetoric, pp.131138, 2013.

[3] Jinil Yoo, "Current State and Perspectives of Hungarian Studies in Republic of Korea," Conference Celebrating the 25th Anniversary of the Establishment of Diplomatic Relations between Korea and Hungary, Korea, pp. 87-95, 2014.

[4] Haksoo Kim et al., The Collected Works of Contemporary Soviet Union and East European Literature, Seoul: Jungangilbo, 1990.

[5] Kosztolányi Dezsö, Pacsirta, Seoul: Jimanji, 2015.

[6] Kertész Imre, Sorstananság, trans: Jinil Yoo, Seoul: Minumsa, 2016.

[7] Márai Sándor, Die Glut, Seoul: Sol, 2008.

[8] Molnár Ferenc, Pál utcai fiuk, Seoul: Biryongso, 2006.

[9] Móricz, Zsigmond, Móricz Zsigmond válogatott novellái, Seoul: Jimanji, 2009.

[10] Han Kyungmin, A magyarirodalom története, Seoul: HUFS, 2004. 